\title{
MICROLEAKAGE OF A RECENT TYPE OF BIOACTIVE RESTORATIVE MATERIALS (ACTIVA) (IN VITRO STUDY)
}

\author{
Dina M. Ghazal ${ }^{1 *}$ BDS Samir A. Koheil2 PhD, Marwa A. Mehesenз PhD.
}

\begin{abstract}
INTRODUCTION: Good sealing ability is a significant physical property of different dental restorative materials. Recently, A new generation has been developed that is termed bioactive, or 'smart,' one of them is Activa that is claimed to have good sealing ability and it is the concern of this research.

OBJECTIVES: This study evaluated the microleakage of a smart bioactive material (Activa bio-active restorative) and compared it to the bulk-fill composite resin (Tetric ${ }^{\circledR} \mathrm{N}-$ Ceram).

MATERIALS AND METHODS: The study included two groups, according to the material used; Group A: Activa (Pulpdent), Group B: Tetric ${ }^{\circledR}$ N-Ceram Bulk-Fill (Ivoclar-Vivadent). The microleakage test was assessed by a bacterial leakage test on 20 extracted premolar teeth 10 for each group. Group A was filled with Activa from the sub-pulpal wall to the occlusal surface that was adjusted for 4mm; the same procedure was performed for group B using the Tetric ${ }^{\circledR} \mathrm{N}$-Ceram. The bacterial leakage of all specimens was assessed in a microbiological laboratory test, bacterial leakage was observed as turbidity. The day of the observation and number of teeth demonstrating bacterial leakage were recorded for each material and the leaked bacteria were counted by a quantitative culture through the serial dilution method.

RESULTS: It was found that Activa showed turbidity in 9 out of ten samples, while Tetric N-Ceram showed turbidity in 8 out of ten samples. Regarding the frequency of bacterial penetration and serial dilution, there were no significant differences between Activa and Tetric N-Ceram.

Results were statistically analyzed using independent sample t-test, paired t-test, and chi-square test.

CONCLUSION: These findings nominate Activa as a restorative material where a good sealing ability is needed.

KEYWORDS: composite, Bioactive, Activa, bacterial leakage.

RUNNING TITLE: microleakage of smart bioactive material (Activa).

1. Bachelor of Dentistry, Faculty of Dentistry, Alexandria University, Egypt.

2. Professor of Conservative Dentistry, Faculty of Dentistry, Alexandria University, Egypt.

3. Assistant Professor of Microbiology, Faculty of Medicine, Alexandria University, Egypt.

* Corresponding Author

E-mail: dinadent1988@gmail.com

\section{INTRODUCTION}

Researches show that bonding agents used with composite restorations degrade over time, which results in microleakage, staining, and restoration failure $(1,2)$. Meticulous oral hygiene maintenance required where the composite is a hydrophobic material that promotes bacterial adhesion that will eventually turn to secondary caries (3). In vitro studies have demonstrated that demineralization depth and degradation of the restorative material is bacterialdependant (3). Restoration longevity, therefore, is related to susceptibility towards bacterial colonization $(2,3)$.

There is constant ongoing research towards the improvement of biological properties of restorative material as well as new adhesives to reduce microleakage and enhance the bond strength. However, despite the advances in these materials, the marginal integrity, which is the most important feature of adhesive restorative materials, remains a challenge that causes the formation of gaps at the tooth-restorative

materials; this may eventually turn in a failure of restorations $(4,5,6)$.

We are searching for a material that prevails over these drawbacks that aimed to be esthetic, durable, having the strength and physical properties of composites, bioactive properties of glass ionomers, and to be hydrophilic, suggesting less bacterial adhesion. The patient can expect extended service from these restorations $(7,8)$.

Activa bio-active material (Pulpdent, USA) is suggested for usage to overcome these problems. It is supposed to meet our needs. It contains no Bisphenol A, no Bis-GMA, and no BPA derivatives and ideally suited for the injection technique where it is delivered via a dual-barrel automix syringe $(9,10)$. It is a bioactive material that is reported to release fluoride, react to $\mathrm{PH}$ changes in the mouth by uptaking calcium, phosphate, and fluoride ions to preserve the chemical integrity of the tooth structure. It contains an
\end{abstract}


enhanced RMGI with a blend of diurethane monomers modified by the insertion of hydrogenated polybutadiene (a synthetic rubber). The purpose of this in vitro study was to evaluate a recent bioactive restorative material (Activa bioactive restorative) using the bacterial leakage test, and compared it with the commonly used bulk fill composite Tetric ${ }^{\circledR} \mathrm{N}$-Ceram. The null hypothesis states that there is no difference in microleakage between Activa and Tetric NCeram.

\section{MATERIALS AND METHODS \\ Materials:}

Twenty premolars

Activa bioactive restorative

Tetric N-Ceram bulk-fill

Etch-Rite (38\% phosphoric acid)

Dentastic UNO bond

Tetric N-bond

\section{Bacteriological materials}

Twenty Falcon tubes

Twenty Glass test tubes

Epoxy resin

Sticky wax

Blood agar

Brain heart infusion broth

Enterococcus Feacalis $\left(9 \times 10^{\circledR}\right.$ Centrifugal $/ \mathrm{ml}$ saline)

Bile esculinagar

Equipment:

Ethylene oxide sterilizer

Autoclave

Laminar flow hood

Incubator

LED curing unit

\section{Methodology:}

Twenty premolar teeth were collected from the out-patient clinics at the Faculty of Dentistry, Oral Surgery Department. The selected teeth were non-carious premolars extracted for orthodontic reasons, with comparable length and size free from attrition, erosion, abrasion, cracking, or previous restorations. Ten teeth were assigned to each group. The study was conducted after exemption from the ethical committee at the Faculty of Dentistry, Alexandria University, Egypt. The teeth were washed thoroughly with running water followed by disinfection with $5.25 \%$ sodium hypochlorite (Naocl) for an hour, and root surfaces were cleaned with a periodontal curette from any tissues then stored in normal saline solution till use (11). Each tooth was prepared occlusaly for access opening of the pulp chamber using Ultra-high-speed handpiece with a round bur and water spray. The occlusal surfaces were trimmed by a diamond disc exposing an occlusal flat surface creating a 4 mm depth of restorative materials from sub pulpal surface to occlusal surface; cavity depth was measured by a graduated periodontal probe (11).

This research studied two groups (table 1).

Group A: specimens of Activa.

Group B: specimens of Tetric ${ }^{\circledR}$ N-Ceram.
Each group will be tested for microleakage by a bacterial leakage test (12).

Canal preparation was done in the step-back technique and kept without filling. The apical third of each root was resected at 90 degrees to it is longs axis, and so a channel was created.

Group A: Etching of the $4 \mathrm{~mm}$ cavity from sub-pulpal surface to the occlusal surface was done for $15 \mathrm{sec}$ by Etch-Rite ${ }^{\mathrm{TM}}$ (38\% phosphoric acid) (Pulpdent, Watertown MA, USA). As directed by the manufacturer, rinsing and leaving the dentin moist for wet bonding technique Followed by applying two coats of bonding agent Dentastic $^{\text {TM }}$ UNO $^{\text {TM }}$ (Pulpdent, Watertown MA, USA), gentle stream of air and light-curing for 10s (Bluephase, NMC, Ivoclar, Vivadent, Austria) The material was placed following the bulk-fill technique of $4 \mathrm{~mm}$ thickness in the prepared teeth of group A. ACTIVA was light-cured for 40 sec., and the surface was covered with glycerine layer and cured for $40 \mathrm{sec}$.

Group B: Tetric ${ }^{\circledR} \mathrm{N}$ bond universal (Ivoclar-Vivadent, Schaan, Liechtenstein) was used in the self-etch technique; it was applied to the entire cavity wall of teeth in 1 coat for 20s with gentle agitation and air thinned for 5s followed by light curing for 10 s. Tetric ${ }^{\circledR} \mathrm{N}$-Ceram was placed in one increment of $4 \mathrm{~mm}$ thickness and light-cured for 40 sec., and the surface was covered with the glycerine layer and cured for $40 \mathrm{sec}$.

The twenty Specimens were stored for $24 \mathrm{hrs}$ in distilled water at $37^{\circ} \mathrm{C}$ and subjected to 1,000 thermal cycles at $5^{\circ} \mathrm{C} / 55^{\circ} \mathrm{C}$ with 30 -second dwell time (11).

\section{Bacterial Leakage Assessment}

The external surface of the experimental teeth specimens was covered by two layers of nail varnish and sticky wax except for the apical 2-3mms. The microbial test was carried out by a microbiologist in a microbiology laboratory under aseptic conditions. The specimens were fixed in a twochamber bacterial model $(13,14,15)$. The upper chamber is a Falcon tube (Lab Supply, Cairo, Egypt), while the lower chamber is a glass test tube (12x75 glass test tube, Dasheng, Jiangsu, China) (Figure 1). The bottom of the Falcon tubes was cut with a heated blade.

Each tooth specimen was embedded in one end of Falcon plastic tube, where the tooth was fixed with two coats of epoxy resin (EPOBOND, Egypt) and sticky wax (Kerr, Calif, USA) to the Falcon tube to ensure the test bacteria could not penetrate between the teeth and the Falcon tubes and this constituting one mount (Figure 2). Each mount was placed in a sterilization bag and sterilized in ethylene oxide sterilizer (CIZA, 55100 Lucca, Italy) for four hours. This was a must despite not being in abundance to avoid thermal damage of the plastic Falcon tubes and the materials used; where its temperature ranges from $25-55{ }^{\circ} \mathrm{C}$. Glass Tubes were sterilized in $116-121^{\circ} \mathrm{C}$ for $10-15 \mathrm{~min}$ in the autoclave (KT series, ALP co., Tokyo, Japan).

30ml brain-heart infusion broth (Lab Supply, Cairo, Egypt) was placed into the sterilized glass tubes. Each mount was placed in the previously sterilized glass tube containing brain-heart infusion broth in sterile laminar flow hood (NS Biotec, Alexandria, Egypt) to avoid bacterial contamination as it provide ultraclean air through upper and lower high 
efficiency particle arrester filter, so that 2-3 $\mathrm{mm}$ of the specimen was embedded in the broth forming one assembly (Figure 3). Junctions between plastic Falcon tubes and the glass tubes were tightly sealed with epoxy resin and sterile cotton plugs to avoid any external contamination $(14,15,16,18)$.

The assemblies were incubated at $37^{\circ} \mathrm{C}$ in an incubator (Series BD Avantgarde.Line, BINDER, Germany) for 72hrs. In order to verify the sterility, samples were picked from the lower chambers with a plastic loop and cultured on blood agar (Lab Supply, Cairo, Egypt). If no growth occurred, it was concluded that the assembly was sterile. If the broth showed any growth, the assembly was discarded and replaced by a new one. A culture containing $9 \times 10^{8} \mathrm{CFU} / \mathrm{ml}$ of Enterococcus feacalis (Faculty of pharmacology, Alexandria, Egypt) was placed with a sterile plastic syringe and (22-gauge needle) into the sterile Falcon tubes in contact with the occlusal surface of the specimen $(15,16,17)$. Lower glass tubes were observed daily, and the turbidity time was recorded for each specimen.

Once turbidity was noticed, a sample of the turbid broth was streaked onto bile esculinagar plates (Lab Supply, Cairo, Egypt) to ensure there was no contamination other than $E$. feacalis, which will be demonstrated as black discoloration but that showed other than E. feacalis was discarded and replaced (16). When turbidity was observed, that was an indication that bacterial leakage had occurred through the tested material passing through the root canal, causing turbidity of the Brain heart infusion broth. Once turbidity was detected, the day of the observation and number of teeth demonstrating bacterial leakage were recorded for each material (18).

The semi-quantitative culture serial dilution method was followed to count the number of leaked bacteria (19) within 24 hours from the appearance of turbidity; where a serial of 10 fold dilution of turbid broth was performed followed by a culture of $10 \mathrm{ml}$ of each dilution on blood agar. Then the bacterial count was calculated using the following formula: Bacterial count per $\mathrm{ml}$ of broth= number of colonies of bacteria $\times$ dilution factor $\times 10^{2}$.

\section{Statistical analysis}

The data were statistically analyzed with SPSS (Statistical Package for Social Science) program for statistical analysis (version 21) using analysis of variance (ANOVA) at the $p<0.05$ significance level Chi-square test was used to test the association between qualitative variables. Monte Carlo correction was carried out when indicated (nxm table).

An alpha level was set to $5 \%$ with a significance level of $95 \%$, and a beta error accepted up to $20 \%$ with a power of study of $80 \%$.

\section{RESULTS}

Our results showed two samples out of Group A, and one sample out of Group B demonstrated evidence of contamination on blood agar as bacterial growth, which was discarded and replaced prior to bacterial leakage test and placing of Enterococcus feacalis into the sterile Falcon tubes.
Our results showed in microleakage test that Activa demonstrated turbidity in 9 out of ten samples while Tetric $\mathrm{N}$ Ceram showed turbidity in 8 out of ten samples, no significant statistical differences were found in terms of frequency of bacterial penetration of Enterococcus feacalis using Pearson Chi-Square test where $(\mathrm{p} \geq 0.05)$ as shown in (table 2 ).

Considering the day of leakage, they could be divided into three intervals.

First interval: From day 1 to 35 days.

Second interval: From day 36 to70 days.

Third interval: From day 71 to105 days.

Statistical analysis revealed no significant differences between groups $\mathrm{A}$ and $\mathrm{B}$ in terms of day of leakage throughout 105 days of study period using Pearson Chi-Square test where $(p \geq 0.05)$ as shown in (table 3 ). Also, the mean leaked bacterial count in group A was $151075.55 \times 10^{6} \pm 243368.77 \times 10^{6}$, while in group B was $1082.875 \times 10^{6} \pm 208249.79 \times 10^{6}$, statistical comparison of the Enterococcus feacalis penetration count revealed that there are no significant differences between Activa and Tetric N-Ceram ( $p \geq 0.05)$ as shown in (table 4$)$.

Table 1: Showing composition and manufacturers of the tested materials.

\begin{tabular}{|c|c|c|}
\hline $\begin{array}{l}\text { Activa Bioactive } \\
\text { composite shade } \\
\text { A2. }\end{array}$ & $\begin{array}{l}\text { Pulpdent, } \\
\text { Watertown, } \\
\text { MA 02472, } \\
\text { USA. }\end{array}$ & $\begin{array}{l}\text { Blend of diurethane and other } \\
\text { methacrylates with modified } \\
\text { polyacrylic acid ((a mixture of } \\
\text { modified polyacrylic acid and } \\
\text { polybutadiene modified diuretene } \\
\text { dimethacrylate with a diurea-on and } \\
\text { methacrylates) (44.6\%), amorphous } \\
\text { silica (6.7\%), and sodium fluoride } \\
(0.75 \%) \text {. }\end{array}$ \\
\hline $\begin{array}{l}\text { Tetric }{ }^{\circledR} \mathrm{N} \text {-Ceram } \\
\text { bulk-fill } \\
\text { composite resin } \\
\text { shade IVA. }\end{array}$ & $\begin{array}{l}\text { Ivoclar- } \\
\text { Vivadent, } \\
\text { Schaan, } \\
\text { Liechtenstein }\end{array}$ & $\begin{array}{l}\text { Resin Matrix: Bis-GMA / UDMA / } \\
\text { Bis-EMA (bisphenol-A-polyethylene } \\
\text { glycol diether dimethacrylate); } \\
\text { Fillers: barium aluminum silicate } \\
\text { glass, an "Isofiller," ytterbium } \\
\text { fluoride, and spherical mixed oxide; } 77 \\
\text { wt\%, } 61 \text { vol\%. } \\
\text { Photoinitiator: camphorquinone plus } \\
\text { an acyl phosphine oxide, together with } \\
\text { a patented initiator Ivocerin }\end{array}$ \\
\hline $\begin{array}{l}\text { Tetric }{ }^{\circledR} \quad \mathrm{N}-\text { Bond } \\
\text { Universal }\end{array}$ & $\begin{array}{l}\text { Ivoclar- } \\
\text { Vivadent, } \\
\text { schaan, } \\
\text { Liechtensteih }\end{array}$ & $\begin{array}{l}\text { HEMA, 10-MDP, MCAP, Bis-GMA, } \\
\text { D3MA, DMAEMA, CQ, ethanol, } \\
\text { water, highly dispersed silicon dioxide. }\end{array}$ \\
\hline $\begin{array}{l}\text { Dentastic }{ }^{\mathrm{TM}} \\
\text { UNO }^{\mathrm{TM}} \text { bond }\end{array}$ & $\begin{array}{l}\text { Pulpdent, } \\
\text { Watertown, } \\
\text { MA 02472, } \\
\text { USA. }\end{array}$ & $\begin{array}{l}\text { Patented PMGDM (pyromellitic } \\
\text { glycerol dimethacrylate; mass fraction } \\
20 \% \text { ) adhesive primer with hydrophilic } \\
\text { resins and acetone solvent and } \\
\text { camphorquinone; (mass fraction } \\
0.028 \% \text { ). }\end{array}$ \\
\hline Etch-Rite $^{\mathrm{TM}}$ & $\begin{array}{l}\text { Pulpdent, } \\
\text { Watertown, } \\
\text { MA 02472, } \\
\text { USA. }\end{array}$ & $\mathrm{H}_{3} \mathrm{PO}_{4} 38 \%$ \\
\hline
\end{tabular}

Table 2: Showing comparison of frequency of bacterial penetration in the two studied groups A, B. 


\begin{tabular}{|c|c|c|c|}
\hline Microleakage & $\begin{array}{c}\text { Subgroup A1 } \\
\text { (Activa Bioactive } \\
\text { Restorative) } \\
\end{array}$ & $\begin{array}{r}\text { Subgroup B1 } \\
\text { (Tetric N-Ceran }\end{array}$ & Total \\
\hline $\begin{array}{l}\text { No turbidity } \\
\text { - n } \\
\text { - \% within } \\
\text { Microleakage } \\
\text { - \% within Group }\end{array}$ & $\begin{array}{c}1 \\
33.33 \% \\
10.00 \%\end{array}$ & $\begin{array}{c}2 \\
66.67 \% \\
20.00 \%\end{array}$ & $\begin{array}{c}3 \\
100.00 \% \\
15.00 \%\end{array}$ \\
\hline $\begin{array}{l}\text { Yes: showed } \\
\text { turbidity } \\
\text { - n } \\
\text { - \% within } \\
\text { Microleakage } \\
\text { - \% within Group }\end{array}$ & $\begin{array}{c}9 \\
52.94 \% \\
90.00 \%\end{array}$ & $\begin{array}{c}8 \\
47.06 \% \\
80.00 \%\end{array}$ & $\begin{array}{c}17 \\
100.00 \% \\
85.00 \%\end{array}$ \\
\hline $\begin{array}{l}\text { Total } \\
-\mathrm{n} \\
\text { - \% within } \\
\text { Microleakage } \\
\text { - \% within Subgroup }\end{array}$ & $\begin{array}{c}10 \\
50.00 \% \\
100.00 \%\end{array}$ & $\begin{array}{c}10 \\
50.00 \% \\
100.00 \%\end{array}$ & $\begin{array}{c}20 \\
100.00 \% \\
100.00 \%\end{array}$ \\
\hline Test of Significance & & $\begin{array}{l}\chi^{2}(\mathrm{df}=1)=0.392 \\
\mathrm{p}=0.531 \mathrm{NS}\end{array}$ & \\
\hline
\end{tabular}

n: Number of specimens

df: the degree of freedom

$\chi^{2}=$ Pearson Chi-Square

NS: Statistically not significant $(\mathrm{p} \geq 0.05)$

Table 3: Showing number of samples showed turbidity per 35day interval throughout the 105 days of the study test period in groups $\mathrm{A}, \mathrm{B}$.

\begin{tabular}{|c|c|c|c|}
\hline $\begin{array}{l}\text { Day of leakage } \\
\text { category }\end{array}$ & $\begin{array}{c}\text { Subgroup A } \\
\text { (Activa Bioactiv } \\
\text { Restorative) }\end{array}$ & $\begin{array}{l}\text { Subgroup B1 } \\
\text { ( Tetric N-Ceram) }\end{array}$ & Total \\
\hline $\begin{array}{l}\text { 1-35 } \\
\text { - n } \\
\text { - \% within Day of } \\
\text { leakage category } \\
\text { - \% within Group }\end{array}$ & $\begin{array}{c}6 \\
50.00 \% \\
60.00 \%\end{array}$ & $\begin{array}{c}6 \\
50.00 \% \\
60.00 \%\end{array}$ & $\begin{array}{c}12 \\
100.00 \% \\
60.00 \%\end{array}$ \\
\hline $\begin{array}{l}\text { 36-70 } \\
\text { - n } \\
\text { - \% within Day of } \\
\text { leakage category } \\
\text { - \% within Group }\end{array}$ & $\begin{array}{c}0 \\
0.00 \% \\
0.00 \%\end{array}$ & $\begin{array}{c}0 \\
0.00 \% \\
0.00 \%\end{array}$ & $\begin{array}{c}0 \\
0.00 \% \\
0.00 \%\end{array}$ \\
\hline $\begin{array}{l}\text { 71-105 } \\
\text { - n } \\
\text { - \% within Day of } \\
\text { leakage category } \\
\text { - \% within Group }\end{array}$ & $\begin{array}{c}3 \\
60.00 \% \\
30.00 \%\end{array}$ & $\begin{array}{c}2 \\
40.00 \% \\
20.00 \%\end{array}$ & $\begin{array}{c}5 \\
100.00 \% \\
25.00 \%\end{array}$ \\
\hline $\begin{array}{l}\text { No turbidity } \\
\text { - n } \\
\text { - \% within Day of } \\
\text { leakage category } \\
\text { - \% within Group }\end{array}$ & $\begin{array}{c}1 \\
33.33 \% \\
10.00 \%\end{array}$ & $\begin{array}{c}2 \\
66.67 \% \\
20.00 \%\end{array}$ & $\begin{array}{c}3 \\
100.00 \% \\
15.00 \%\end{array}$ \\
\hline $\begin{array}{l}\text { Total } \\
\text { - n } \\
\text { - \% within Day of } \\
\text { leakage category } \\
\text { - \% within Group }\end{array}$ & $\begin{array}{c}10 \\
50.00 \% \\
100.00 \%\end{array}$ & $\begin{array}{c}10 \\
50.00 \% \\
100.00 \%\end{array}$ & $\begin{array}{c}20 \\
100.00 \% \\
100.00 \%\end{array}$ \\
\hline $\begin{array}{l}\text { Test of } \\
\text { Significance }\end{array}$ & & $\begin{array}{l}\chi^{2}{ }_{(\mathrm{df}=3)}=0.533 \\
\mathrm{P}(\mathrm{MC})=1.000 \mathrm{NS}\end{array}$ & \\
\hline
\end{tabular}

n: Number of specimens

NS: Statistically not significant $(\mathrm{p} \geq 0.05)$

$\chi^{2}=$ Pearson Chi-Square

$\mathrm{df}$ : the degree of freedom

Table 4: Showing comparison of mean bacterial penetration count values in the two groups A, B.

\begin{tabular}{|l|c|c||}
\hline & $\begin{array}{c}\text { Activa Bioactive } \\
\text { Restorative }\end{array}$ & Tetric N-Ceram \\
\hline
\end{tabular}

\begin{tabular}{|l|c|c|}
\hline Bacterial count & 9 & 8 \\
$-\mathrm{n}$ & $1.8 \times 10^{6}-7000 \times 10^{6}$ & $10 \times 10^{6}-6000 \times 10^{6}$ \\
- Min-Max & $151075.55 \times 10^{6} \pm 2433$ & $1082.875 \times 10^{6} \pm 208249.79 \times 10^{6}$ \\
- Mean \pm Std. & $68.77 \times 10^{6}$ & $-6581368.23 \times 10^{6}-28238868.23 \times 10^{6}$ \\
Deviation & $-3599424.21 \times 10^{6}-$ & \\
$-95 \%$ CI for mean & $33814535.32 \times 10^{6}$ & \\
\hline Test of significance & \multicolumn{2}{|c|}{$\mathrm{t}_{(\mathrm{df}=15)}=0.387$} \\
& & $p=0.704 \mathrm{NS}$ \\
\hline
\end{tabular}

n: Number of specimens

NS: Statistically not significant $(\mathrm{p} \geq 0.05)$

df: the degree of freedom

CI: Confidence interval

\section{DISCUSSION}

The bacterial leakage test was performed in the present study. An important advantage of this method is its clinical relevance (20). It is a technique that basically was described to test bacterial leakage around filling materials (13).

Uniform box-shaped class I cavities with $4 \mathrm{~mm}$ depth (corresponding to curing depth of bulk-fill composite), were performed. However, it is associated with high C-factor, polymerization shrinkage, and stresses that pose a restorative challenge (21); this is in accordance with Horieh Moosavi et al. and Osvaldo Zmener et al., who did the bacterial leakage test on teeth prepared for class I cavity $(12,18)$.

Enterococcus feacalis bacteria were chosen in our study because they are common in the oral dental infections as found by Wang Q Q et al. (22), and Liu H, Wei X et al. (23). Two specimens of Activa group $\mathrm{A}$ and one specimen of Tetric N-Ceram group $\mathrm{B}$ were discarded and replaced because turbidity was detected before continuing of the bacterial test. The sterility of both falcon and glass tubes are essential for the performance of the test of all the specimens and should be assured to exclude any other bacterial contamination before the start of the bacterial microleakage; this coincides with Horieh Moosavi et al., (12), Osvaldo Zmener et al. (18); who assured the sterility of both upper and lower chambers to ensure that there was no bacterial contamination.

Regarding microleakage evaluation, a qualitative method (presence or absence of turbidity) and quantitative method (serial dilution) which count the amount of leaked bacteria along the restoration margins were used. The evaluation period used for detection of bacteria in the lower chamber was 115 days. This observation period was about what has been frequently used in rehabilitation before the final restorations; this is matched with Kersting, Miranskij (24), Mi-Young Song (25); who did interim provisional restorations for three months in composite before definitive final ceramic restorations. Zmener et al. (18); who followed the microleakage bacterial test for 60 days evaluation period. 
Our results showed turbidity in nine out of ten specimens of group A (Activa) in the glass tube broth (Fig. 4), while the group B (Tertric N-Ceram) specimens demonstrated turbidity in eight out of ten specimens throughout the study period (Fig. 5). No significant statistical differences were found in terms of the frequency of bacterial penetration of Enterococcus feacalis in the two tested materials. This result could be attributed to the fact that Activa is a material with ionic resin network and bioactive fillers which can reduce the polymerization shrinkage and hence can establish an effective sealing with less bacterial leakage. The ionic resin component contains phosphate acid groups. Hydrogen ions break off from these groups in the ionization process and replaced by calcium in tooth structure, forming a strong resinhydroxyapatite complex (26). This reaction binds the resin to the minerals in the tooth structure, resulting in knitting the tooth and restorations together (27), this is in agreement with Kaushik, Yadav (28); who found that the lower microleakage was found in the group restored with Activa Bioactive restorative in combination with Tetric $\mathrm{N}$ bond in comparison with nanohybrid composite, Zmener et al. (18); who found no leakage in 7 samples of Activa out of ten samples after 60 day incubation period.

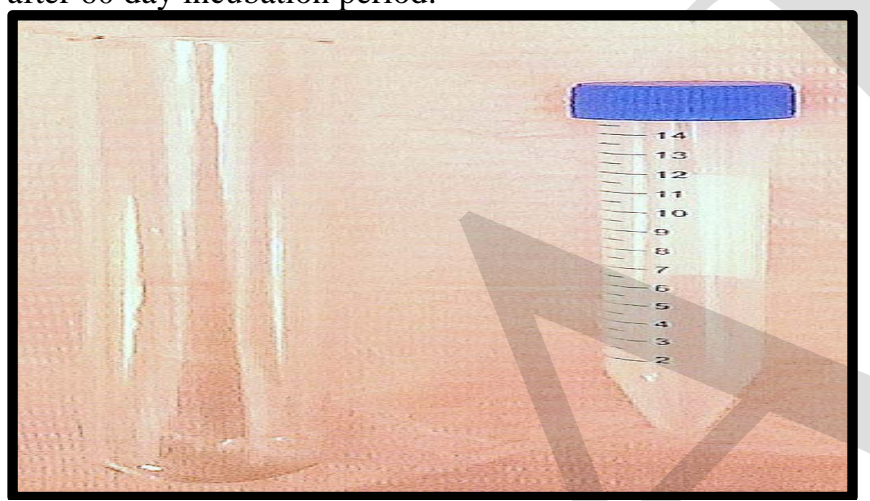

Figure (1): The upper chamber (Falcon tube), while the lower chamber (glass test tube).

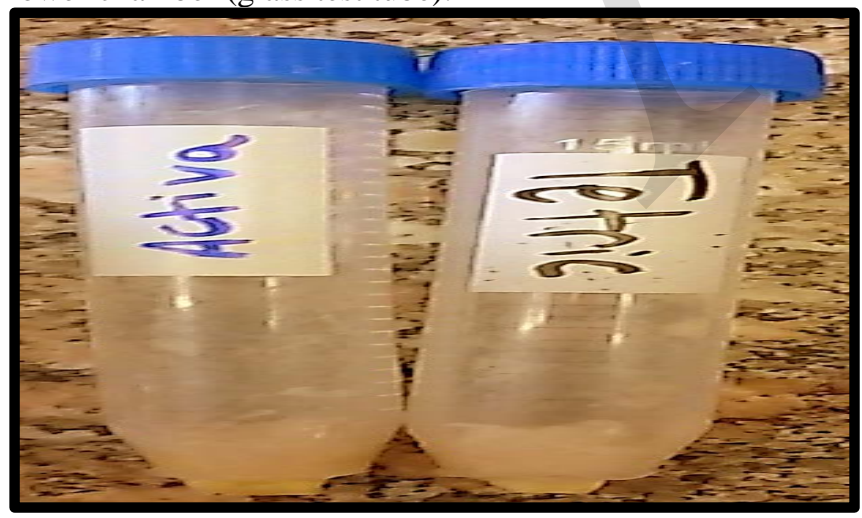

Figure (2): A tooth fixed at one end of Falcon tube constituting one mount.

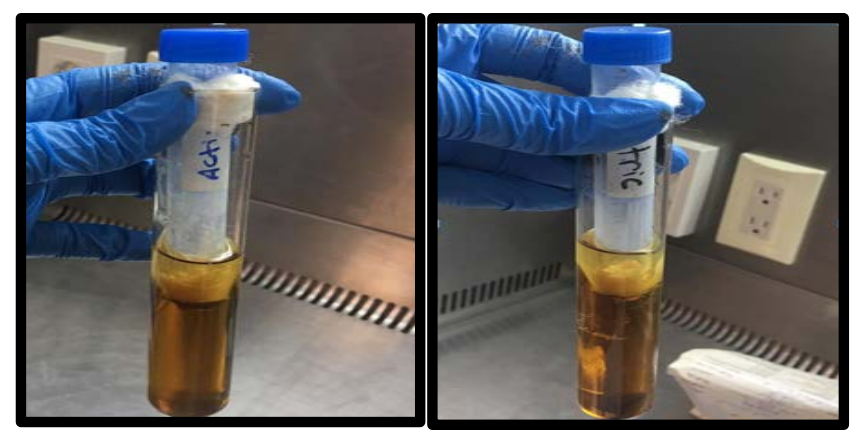

Figure 3): The assemblies handled under a sterile laminar flow hood.

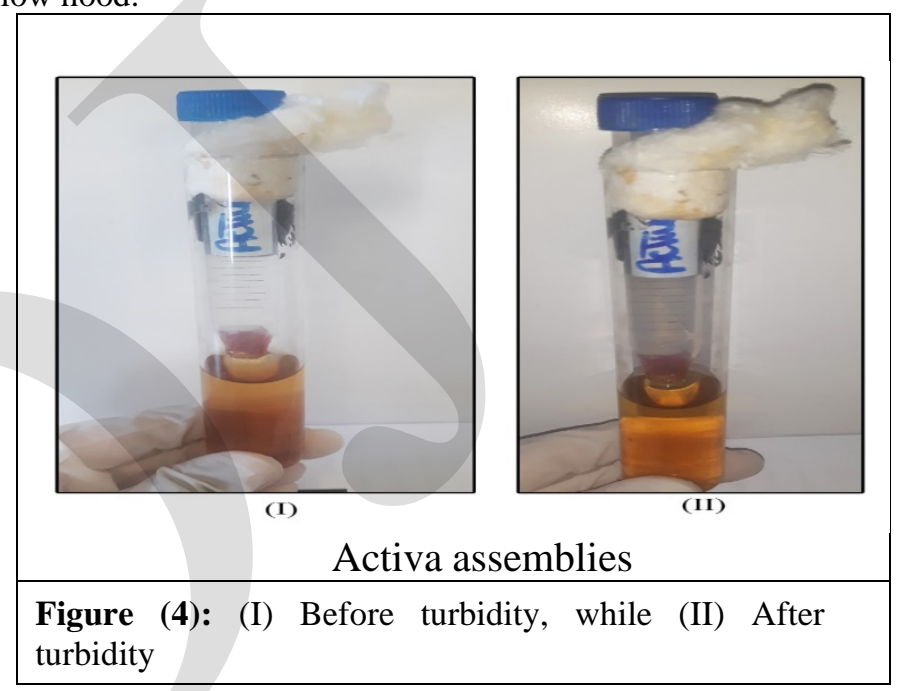

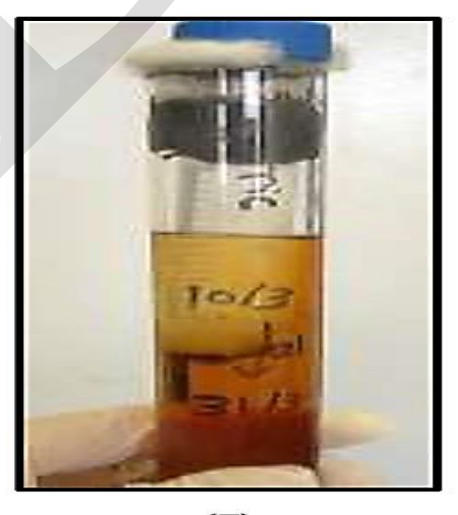

(I)

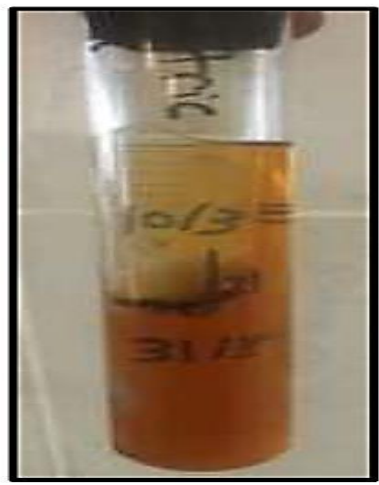

(II)
Tetric N- Ceram assemblies

Figure 5: (I) Before turbidity (II) After turbidity.

Our study also showed throughout the three-time intervals of 105 days of the study period there is no significant statistical difference in terms of day of leakage. This result might be due to the possible antimicrobial benefits of fluoride, calcium and phosphate ion release which can be attenuated as a contributing factor of defense against bacteria, thus reducing bacterial leakage. This agreed with May E, Donly KJ who found that Activa does uptake fluoride 
and re-release it (29) also these findings coincide with Kaushik, Yadav (28), Naorungroj et al. (26) and Zmener et al. (18), Pameijer et al. (30), and Murali et al. found that the fluoride ions released from Activa are able to penetrate through the adhesive bonding agents tested to the tooth structure (31).

Regarding the serial dilution of the bacterial count, our results showed the minimum count number of leaked bacteria was scored by Activa, while the total mean bacterial count of Activa and Tetric N-Ceram leaked into the glass tubes were statistically insignificant. This could be due to that Activa is a hydrophilic material unlike hydrophobic composites that suggests less bacterial adhesion to its surface and enhanced adaptation to the tooth substrate with better moisture tolerance, which means fewer microorganisms' penetration to the dentinal tubules (32). The findings were in accordance with Cannavo et al., who stated that Activa without bonding agent compared favorably to conventional and bulk-fill composites (33). These findings agreed with kubde et al., who found that the sealing ability of Activa with bonding agent was positively comparable to Tetric NCeram (34), Owens et al. who found no significant statistical differences between Activa and composite in terms of microleakage (35), and Omidi, Naeini et al. who found that the microleakage of Activa in the absence or presence of etching and bonding could be comparable to the microleakage of composites (36). While the results were in disagreement with Alkhudairy \& Ahmad, who also tested microleakage of several bulk-fill bioactive restoratives by dye penetration method and reported that Activa showed a moderate degree of microleakage (37). Also, Nathaniel Denson et al. found lower bacterial adhesion and biofilm formation on Filtek and Esthet- $x$ composites than Activa owing to their small filler particles (38).

\section{CONCLUSIONS}

Under the limitations of the present study, it was concluded that leakage occurred in both Activa and Tetric N-Ceram but the difference was statistically not significant. Therefore, the null hypothesis was accepted. This finding nominates Activa as a restorative material comparable to nanohybrid composites regarding their sealing ability.

\section{CONFLICT OF INTEREST:}

The authors declare that they have no conflicts of interest.

\section{ACKNOWLEDGMENTS:}

I would like to thank professor doctor Samir Koheil for his contionous support during the conduction of this study.
1. Drummond JL. Degradation, fatigue, and failure of resin dental composite materials. J Dent Res 2008; 87: 710-9.

2. Spencer P, Jonggu Park QY, Misra A, Bohaty BS, Singh V, Parthasarathy R, Sene F, de Paiva Gonçalves SE, Laurence J. Durable bonds at the adhesive/dentin interface: an impossible mission or simply a moving target? Braz Dent Sci. 2012; 15: 4-18.

3. Cazzaniga G, Ottobelli M, Ionescu A, GarciaGodoy F, Brambilla E. Surface properties of resinbased composite materials and biofilm formation: A review of the current literature. Am J Dent 2015; 28 : 311-20.

4. Carvalho RM, Manso AP, Geraldeli S, Tay FR, Pashley DH. Durability of bonds and clinical success of adhesive restorations. Dent Mater 2012; 28: 72-86.

5. Kopperud, Simen \& Bjørg Tveit, Anne \& Gaarden, Torunn \& Sandvik, Leiv \& Espelid, Ivar. Longevity of posterior dental restorations and reasons for failure. Eur J Oral Sci 2012; 120: 539-48.

6. Mehdawi I, Neel EA, Valappil SP, Palmer G, Salih V, Pratten J, Spratt DA, Young AM. Development of remineralizing, antibacterial dental materials. Acta Biomater 2009; 5: 2525-39.

7. Slowikowski L, John S, Finkleman M, Perry R, Harsono M, Kugel G. Fluoride ion release and recharge over time in three restoratives. J Dent Res 2014; 93 (Spec IssA): 268.

8. Sufyan Garoushi s, Pekka K. Vallittu and Lippo Lassila. Characterization of fluoride releasing restorative dental materials. Dent Mater J 2018; 37(2): 293-300.

9. Bansal R, Burgess J, Lawson NC. Wear of an enhanced resinmodified glass-ionomer restorative material. Am J Dent 2016; 29: 171-4.

10. Croll TP, Berg JH, Donly KJ. Dental repair material: a resinmodified glass-ionomer bioactive ionic resin-based composite. Compend Contin Educ Dent 2015; 36: 60-6.

11. Moosavi H, Afshari E, Forghani M, Ghazvini K, Velayati F: Bacterial Leakage Assessment for Different Types of Resin-Based Dental Restorations Applied Using Various Placement Methods. J Dent Mater Tech 2014; 3(4): 158-65.

12. Alani AH, Toh CG. Detection of microleakage around dental restorations: A review. Oper Dent 1997; 22: 173-85.

13. Fayyad MA, Ball PC. Bacterial penetration around amalgam restorations. J Prosthet Dent. 1987; 57:571-4.

14. Deveaux E, Hildelbert P, Neut C, Romond C, Bacterial microleakage of Cavit, IRM, TERM, and Fermit: A 21-day in vitro study. J Endod. 1999; 25: 653-659.

\section{REFERENCES}


15. Moradi S, Lomee M, Gharechahi M. Comparison of fluid filtration and bacterial leakage techniques for evaluation of microleakage in endodontics. Dent Res $J$ (Isfahan) 2015; 12: 109-114.

16. Križnar I, Seme K, Fidler A. Bacterial microleakage of temporary filling materials used for endodontic access cavity sealing. J Dent Sci. 2016; 11: 394-400.

17. Jacob S, Raj Kumar K, Lakshmi Narayanan L, Evaluation with and without smear layer: A bacterial penetration study. J. Endod. 2000; 12.

18. Zmener O, Pameijer $\mathrm{CH}$, Hernandez S. Resistance against bacterial leakage of four luting agents used for cementation of complete cast crowns. Am J Dent. 2014; 27: 51-55.

19. Kapralos V, Koutroulis A, Ørstavik D, Sunde PT, Rukke HV. Antibacterial Activity of Endodontic Sealers against Planktonic Bacteria and Bacteria in Biofilms. J Endod. 2018; 44: 149-154.

20. Wahab FK, Shaini FJ, Morgano SM. The effect of thermocycling on microleakage of several commercially available composite Class V restorations in vitro. J Prosthet Dent 2003; 90: 168-74.

21. dos Santos G.O., dos Santos M.E., Sampaio E.M., Dias K.R., da Silva E.M. Influence of C-factor and light-curing mode on gap formation in resin composite restorations. Oper Dent. 2009; 34: 544-550.

22. Wang QQ, Zhang $\mathrm{CF}$, Chu $\mathrm{CH}$, Zhu XF. Prevalence of Enterococcus faecalis in saliva and filled root canals of teeth associated with apical periodontitis. Int J Oral Sci. 2012 Mar; 4: 19-23.

23. Liu H, Wei X, Ling J, et al. Biofilm formation capability of Enterococcus faecalis cells in starvation phase and its susceptibility to sodium hypochlorite. J Endod. 2010; 36 4: 630-635.

24. Kersting J, Miranskij A. Minimally invasive restoration of abraded dentition according to functional and esthetic aspects. International Dentistry - African Edition. 2015; 5.

25. Song MY, Park JM, Park EJ. Full mouth rehabilitation of the patient with severely worn dentition: a case report. J Adv Prosthodont. 2010; 2: 106-110.

26. Naorungroj S, Wei HH, Arnold RR, Swift EJ, Walter R. Antibacterial surface properties of fluoridecontaining resin-based sealants. J Dent. 2010; 38: 387-91.

27. The Future of Dentistry Now in Your Hands. Watertown, MA: Pulpdent Corporation; 2014.

28. Kaushik M, Yadav M. Marginal Microleakage Properties of Activa Bioactive Restorative and Nanohybrid Composite Resin Using Two Different Adhesives In Non Carious Cervical Lesions - An In Vitro Study. J West Afr Coll Surg. 2017; 7: 1-14.
29. May E, Donly KJ. Fluoride release and re-release from a bioactive restorative material. Am J Dent. 2017; 30: 305-308.

30. Cornelis H. Pameijer, Franklin Garcia-Godoy, Brian R. Morrow and Steven R. Jefferies. Flexural Strength and Flexural Fatigue Properties of ResinModified Glass Ionomers .J Clin Dent 2015; 26: 23-27.

31. Murali S, Epstein N, Perry R, Kugel G. Fluoride Release of Bioactive Restorative with Bonding Agents. J Dent Res 95 (Spec Iss A) S0368, 2016

32. Li Y, Carrera C, Chen R, Li J, Lenton P, Rudney JD, Jones RS, Aparicio C and Fok A. Degradation in the dentin-composite interface subjected to multi-species biofilm challenges. Acta Biomater. 2014; 10: 375-83.

33. Cannavo M, Harsono M, Finkelman M, Kugel G. Microleakage of dental bulk fill, conventional and self-adhesive composites [abstract]. J Dent Res. 2014; 93 (Spec Issue A):847.

34. Kubde Rajesh., Giradkar Alhad, Pradeep Sonal Dhote, Sneha Sundaram Sneha, Bindra Ishani. Photospectrometric Analysis of The Microleakage Of New Restorative Material (Activa) As Compared To Nanofilled Composite And Light Curing Gic: An In Vitro Study. Int J Dent Health Sci 2017; 4: 859-866.

35. Owens BM, Phebus JG, Johnson WW. Evaluation of the marginal integrity of a bioactive restorative material. Gen Dent. 2018; 66: 32-36.

36. Omidi BR, Naeini FF, Dehghan H, Tamiz P, Savadroodbari MM, Jabbarian R. Microleakage of an Enhanced Resin-Modified Glass Ionomer Restorative Material in Primary Molars. J Dent (Tehran). 2018; 15: 205-213.

37. Alkhudhairy FI, Ahmad ZH. Comparison of Shear Bond Strength and Microleakage of Various Bulk-fill Bioactive Dentin substitutes: An in vitro Study. J Contemp Dent Pract. 2016; 17: 997-1002.

38. Nathaniel Denson, Martha Wells, David A Tipton, Franklin Garcia Godoy and Jegdish P. Bacterial adhesion and oral biofilm formation on Direct tooth colored restorative materials. An in vitro study. Adv Dent \& oral health. 2018; 8: 555736. 